\title{
Computer Tomography Scanners in Portugal (1990-2011)
}

\section{Equipamentos de Tomografia Computorizada em Portugal (1990-2011)}

\author{
Ricardo Crispim ${ }^{1}$, Ana Luisa Vieira ${ }^{2,3}$ \\ ${ }^{1}$ Faculdade de Engenharia, Universidade Católica Portuguesa, 2635-631 Rio de Mouro \\ ${ }^{2}$ CBIOS, Faculdade de Ciências e Tecnologias da Saúde, Universidade Lusófona, Campo Grande 376, 1649-024 Lisboa, \\ PORTUGAL \\ ${ }^{3}$ ERISA - Escola Superior de Saúde Ribeiro Sanches, Rua do Telhal aos Olivais, n8 - 8a, 1900-693 Lisboa \\ Email: ricardocrispims@gmail.com
}

\begin{abstract}
The use of Computed Tomography (CT) has increased every year since its introduction into medicine in 1972. Technological developments have made CT one of the most important imaging modalities in modern medicine. This importance is evidenced in the increasing demand and number of CT scanners installed in Portugal and worldwide. This review compiles the most recent national statistics from official publications on the number of CT scanners installed in Portugal and compares them with data available in international publications. We conclude that the number of CT scanners installed in Portugal exceeded the EU27 average by $61.5 \%$ and the OECD average by $78.2 \%$, and that in 2011 there were 203 CT scanners installed in hospitals in Portugal, which equated to 19.23 CT scanners per million inhabitants.
\end{abstract}

Keywords: Computed Tomography scanners, Computed Tomography, statistics, Portugal

\section{Resumo}

O recurso à Tomografia Computorizada (TC) tem aumentado anualmente desde a sua introdução na medicina em 1972. A evolução tecnológica permitiu que se assumisse atualmente como uma das modalidades de imagem mais importantes na medicina atual. Tal evidência está manifesta na crescente procura e no aumento do número de equipamentos instalados em Portugal e no mundo. Esta revisão compila os dados nacionais mais recentes, de publicações estatísticas oficiais, sobre o número de equipamentos de TC instalados em Portugal, e compara-os com os dados disponíveis em publicações internacionais. Concluiu-se que o número de equipamentos de TC instalados em Portugal superou a média da EU 27 em 61,5 \% e a média da OCDE em 78,2 \% e, que em 2011 existiam 203 equipamentos de TC instalados em meio hospitalar em Portugal, aos quais correspondia 19,23 equipamentos por milhão de habitante.

Palavras-chave: Equipamentos de Tomografia Computorizada, Tomografia computorizada, estatística, Portugal 


\section{Introduction}

Computed Tomography (CT) was introduced in clinical practice in 1972 (Hounsfield \& Cormack, EMI Laboratories, England) [1] for tomographic studies of the chest and abdomen [2-4] and brain [5.6]. Since then, CT has undergone major technological developments that have led to increased use in various clinical specialties, and an increase in the availability of scanners in hospitals and other health centres. Technological improvements, such as in the acquisition geometry and type and in the configuration of detectors, enable a simultaneous irradiation of major anatomical lengths with a consequent reduction in acquisition time and valuable improvement in image quality $[1,7]$.

Currently, CT is assumed as an essential imaging diagnostic technique, evidenced by the increasing number of scanners installed worldwide [8,9]. However, the use of CT in diagnosis and follow-up has health risks to patients due to the use of low energy ionizing radiation [10]. The increased number of CT scanners installed was associated with a rise in collective effective dose and effective dose per capita resulting from medical exposures, and $\mathrm{CT}$ was considered as one of the main dose booster agents [11], both international and nationally [12].

Therefore, the worldwide clinical and scientific community has been struggling to define strategies to minimize these risks, supported by the principles of radiation protection [13]. The knowledge of the number and distribution of CT scanners, as well as the degree of technological development may permit the foundation of national strategies that set dose reference levels institutionally [13], combined with the justification and optimization of procedures adapted to each type of CT scanner.

\section{Number of CT devices in Portugal}

The number of CT scanners installed in Portugal is an indicator of CT availability in the national reality. Between 1990 and 2006 it was observed an increasing trend on the number of CT scanners installed, with a fivefold increase within that period. This growth was accompanied by an increase in the number of CT examinations performed [14].

According to the Organization for Economic Cooperation and Development (OECD), between 1999 and $2008^{1}$, the total number of CT scanners installed in Portugal increased by almost 40 \% (Figure 1). In 2008

\footnotetext{
1 Last year with available data on the total number of scanners installed in Portugal (scanners installed in hospitals and in ambulatory).
}

\section{Introdução}

A Tomografia Computorizada (TC) foi introduzida na prática clínica em 1972 (Hounsfield \& Cormack, Laboratórios EMI, Inglaterra) [1] com indicação para utilização da valência imagiológica em estudos tomográficos do tórax e do abdómen [2-4] e do encéfalo [5,6]. Desde então, a TC tem sofrido importantes desenvolvimentos tecnológicos que se manifestaram na sua crescente utilização em diversas especialidades clínicas e no aumento da disponibilidade da valência a nível intra e extra-hospitalar. As melhorias tecnológicas notaram-se, por exemplo, na geometria de aquisição e tipo e configuração de detetores, o que permitiu a irradiação em simultâneo de maiores volumes anatómicos com uma consequente redução no tempo de aquisição e uma valiosa melhoria na qualidade de imagem $[1,7]$.

Atualmente, a TC assume-se como uma valência de imagem essencial em medicina de diagnóstico, caracterizada pelo crescente número de equipamentos instalados em todo o mundo $[8,9]$. Contudo, o recurso à $\mathrm{TC}$ em diagnóstico e follow-up clínico acarreta riscos para os pacientes, associados à utilização de radiação ionizante de baixa energia [10]. Concomitantemente ao aumento do número de equipamentos de TC instalados, verificou-se um aumento da dose efetiva coletiva e dose efetiva per capita decorrente das exposições médicas, tendo-se a TC assumido como um dos principais impulsionadores [11], tando a nível internacional como nacional [12].

Neste sentido, tem havido um esforço na comunidade clínica e científica para definição de estratégias de minimização destes riscos, apoiadas nos princípios da proteção radiológica [13]. O conhecimento do número e distribuição dos equipamentos de TC, bem como o conhecimento do grau de evolução tecnológica, permitem lançar as bases de estratégias nacionais que visam a acertada definição de níveis de referência de dose definidos a nível local [13], englobadas na justificação das práticas e na otimização de procedimentos técnicos adequados ao tipo de equipamento de TC.

\section{Número de equipamentos em Portugal}

$\mathrm{O}$ número de equipamentos de $\mathrm{TC}$ instalados em Portugal permite inferir sobre a disponibilidade da técnica na realidade nacional. Entre 1990 e 2006 constatou-se uma tendência crescente do número de equipamentos de TC instalados, tento quintuplicado nesse intervalo. Este crescimento foi acompanhado pelo aumento do número de exames de TC realizados [14].

Segundo a Organização para a Cooperação e Desenvolvimento Económico (OCDE), entre 1999 e 2008¹, o número total de equipamentos de TC instalados em Portugal aumentou quase 40 \% (Figura 1). Em 2008 existia

\footnotetext{
1 Último ano com dados disponíveis sobre o número total de equipamentos instalados em Portugal (equipamentos instalados em meio hospitalar e equipamentos instalados em ambulatório).
} 
there were a total of 291 CT scanners in Portugal, which corresponded to an average of 27.4 scanners per million inhabitants. Data after 2008 are available online by the OECD [8], but only for the number of CT scanners installed in hospitals (Table 1).

For the CT scanners installed in hospitals, it was found that their actual number almost tripled between 1999 and $2011^{2}$, reaching 19.23 scanners per million inhabitants. But it was in the later years of this interval that the highest growth rates were observed. Between 2009 and 2010 , the number of CT scanners per million inhabitants grew more than 13\%, and between 2010 and 2011 this number increased by nearly $28 \%$. The actual number of CT scanners installed rose from 147 in 2010 to a total of 203 in 2011 (Figure 1, Table 1).

Considering placements outside hospitals, a small decrease on the number of CT scanners installed was observed between 2005 and $2008^{3}$, which was most evident between 2005 and 2007 (Table 1). Despite this downward trend, between 2007 and 2008 an increase of nearly $7 \%$ was reported on the effective number and on the number of scanners normalized to the population. um total de 291 equipamentos de TC no território nacional, aos quais correspondia uma média de 27,4 equipamentos por milhão de habitantes. Dados posteriores a 2008 são disponibilizados online pela OCDE [8] mas relativos ao número de equipamentos instalados apenas em meio hospitalar (Tabela 1).

Dos equipamentos instalados em meio hospitalar, entre 1999 e $2011^{2}$, verificou-se que o seu número efetivo quase triplicou, quando se atingiu os 19,23 equipamentos por milhão de habitantes. Mas foi nos últimos anos deste intervalo que se observou o maior crescimento. Só entre 2009 e 2010 o número de equipamentos de TC por milhão de habitantes cresceu mais de $13 \%$ e, entre 2010 e 2011 cresceu quase $28 \%$. O número efetivo de equipamentos instalados passou de 147, em 2010, para um total de 203, em 2011 (Figura 1, Tabela 1).

Quanto aos equipamentos instalados apenas em ambulatório, entre 2005 e $2008^{3}$, observou-se um decréscimo do seu número efetivo (Tabela 1), tendo sido mais evidente entre 2005 e 2007 . Apesar desta tendência decrescente, entre 2007 e 2008 foi registado um aumento de quase $7 \%$, quer do número efetivo, quer do número de equipamentos normalizado à população. Em 2008

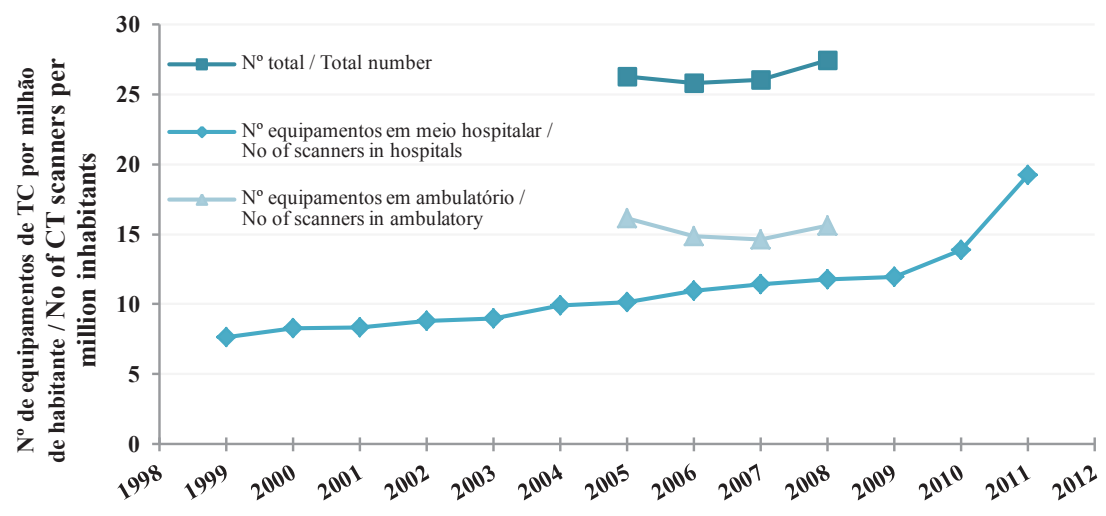

Figure 1 / Figura 1 - Number of CT scanners installed in Portugal per million inhabitants, in hospitals and in ambulatory care, between 1999 and 2011.

Número de equipamentos de TC instalados em Portugal, normalizados à população, em meio hospitalar e ambulatório no período entre 1999 e 2011 . [8]

2 Last year with available data on the number of scanners installed in hospitals in Portugal

3 Last year with available data on the number of scanners installed in ambulatory care facilities in Portugal
2 Último ano com dados disponíveis sobre o número de equipamentos instalados em meio hospitalar em Portugal.

3 Último ano com dados disponíveis sobre o número de equipamentos instalados em ambulatório em Portugal. 
Table 1 / Tabela 1 - Effective number of CT scanners and number of CT scanners normalized (per million inhabitants) between 1999 and 2011. / Número efetivo de equipamentos de TC e número de equipamentos de TC normalizado (por milhão de habitantes) entre 1999 e 2011 [8].

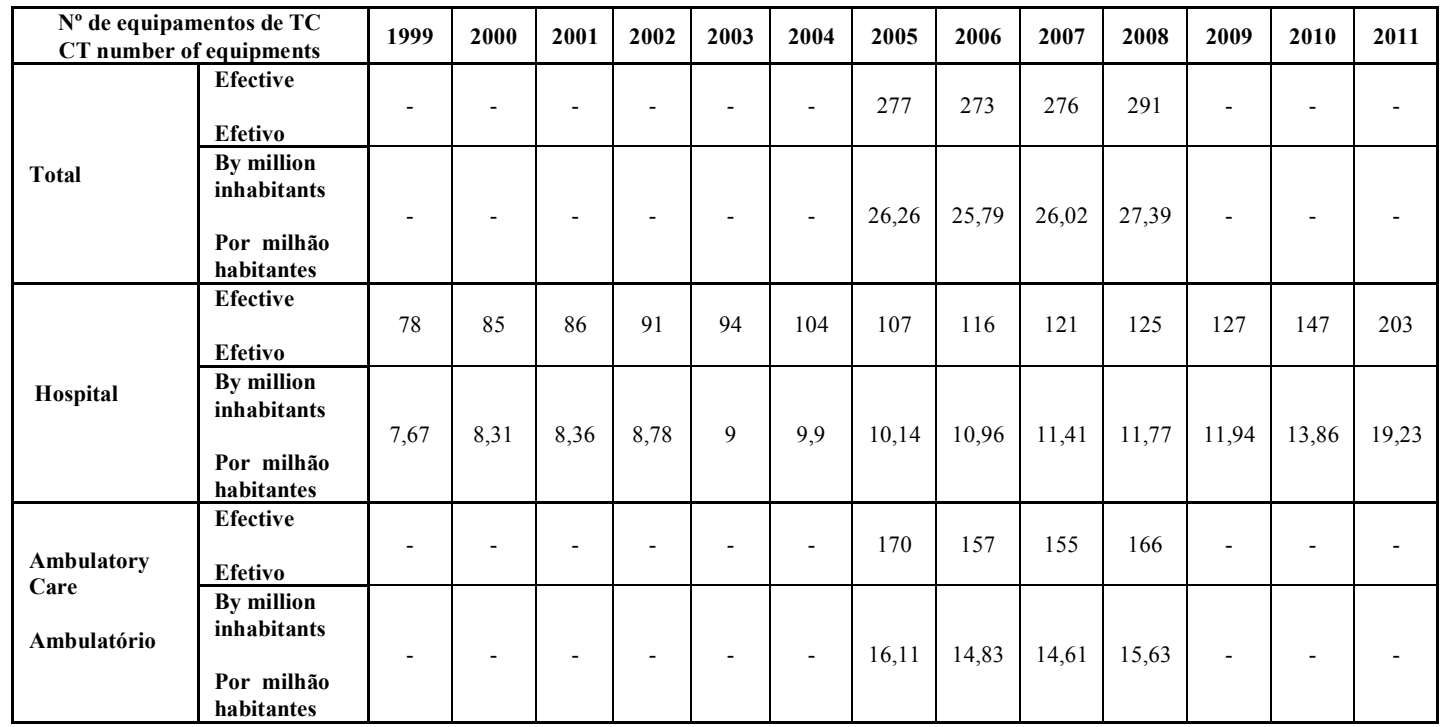

In 2008 there were $166 \mathrm{CT}$ scanners installed outside hospitals in Portugal.

Table 1 shows that the only data known about the total number of CT scanners (in hospitals and outside hospitals) refers to the period between 2005 and 2008. Within this period, an increase of $13.9 \%$ was reported in the number of CT scanners per million inhabitants installed in hospitals and a decrease of $3.0 \%$ in the number of CT scanners installed in ambulatory care facilities. Even so, the total number of scanners grew $4.1 \%$ (Figure 1). Between 2005 and 2008, the share of the number of CT scanners installed in hospitals on the total number of CT scanners installed in Portugal increased from $38.6 \%$ to $43.0 \%$ (Figure 1).

At the time of this article's submission, the national geographic distribution of CT scanners was not known from the published literature consulted. However, the distribution of imaging facilities in Portugal was known. In a study published in 2009 [14], where the competitive market of imaging facilities was analysed, the Regulatory Authority for Health concluded that the geographic dispersion of these facilities was heterogeneous in the continent. The authors also concluded that there were a greater number of imaging facilities in Reference Regions for Health Evaluation (RRHE) of Lisbon and Porto (Table 2). However, the highest concentration of imaging establishments per 100,000 inhabitants was observed in the RRHE of Beja, Sines and Évora, in part due to the lower population density (Table 2). existiam 166 equipamentos de TC instalados em ambulatório em Portugal.

Da análise da Tabela 1, constatou-se apenas se conhecer o número total (hospitais e ambulatório) de equipamentos instalados entre 2005 e 2008 . Neste intervalo, registou-se um aumento de 13,9 \% no número de equipamentos por milhão de habitantes instalados em meio hospitalar e um decréscimo de 3,0\% dos instalados em ambulatório. Ainda assim, o número total de equipamentos cresceu 4,1\% (Figura 1). Nesse período, a representatividade do número de equipamentos de TC instalados em meio hospitalar sobre o total de equipamentos instalados a nível nacional cresceu de $38.6 \%$ para $43.0 \%$ (Figura 1 ).

Da literatura publicada consultada, à data da submissão deste artigo, não eram conhecidos dados sobre a dispersão dos equipamentos de TC pelo território nacional, embora fosse conhecida a distribuição das entidades de imagiologia no território nacional continental. Num estudo publicado em 2009 [14], onde se analisou a concorrência dos mercados das entidades de imagiologia, a Entidade Reguladora da Saúde concluiu que a dispersão geográfica destes estabelecimentos era heterogénea no continente. Concluiu-se a existência de um maior número de estabelecimentos de imagiologia nas Regiões de Referência para Avaliação em Saúde (RRAS) de Lisboa e do Porto (Tabela 2). Porém, a maior concentração de estabelecimentos por 100.000 habitante foi observada nas RRAS de Beja, Sines e Évora, em parte devido à menor densidade populacional (Tabela 2). 
According to official national publications, in 2010 there were two CT scanners installed in the Autonomous Region of Madeira [15]. In the most recent national health statistic reports - Health General Directorate, Regional Statistics Service of the Azores and Regional Directorate of Statistics of Madeira - there was no data on the number of CT scanners installed [16-18].

Moreover, the available statistics do not allow analysis to the level of technological upgrades to installed scanners, making impossible any kind of massive technological cataloguing of CT scanners installed in Portugal. This is an important aspect given the rapid evolution of the technology. At the time of publication of their work, Pascoal et al. stated that "from the contact with users was known to exist a significant number of obsolete equipments (multislice 1-4) in hospitals and
De publicações oficiais nacionais apenas se sabia que, em 2010, existiam dois equipamentos de TC instalados na Região Autónoma da Madeira [15]. Nos relatórios referentes às estatísticas na saúde nacional mais recentes - Direção Geral da Saúde, Serviço Regional de Estatística dos Açores e Direção Regional de Estatística da Madeira - não constavam dados sobre o número de equipamentos instalados [16-18].

As estatísticas disponíveis não permitem analisar o nível de atualização tecnológica dos equipamentos instalados, impossibilitando qualquer tipo de catalogação tecnológica massiva dos equipamentos de TC instalados em Portugal, aspeto este importante face à rápida evolução da tecnologia. À data da publicação do seu trabalho, Pascoal et al afirmaram que "do contacto com os utilizadores se sabia existir um número significativo de equipamentos obsoletos (1-4 cortes) nos hospitais

Table 2 / Tabela 2 - Distribution of the number of entities based on each RRHE, the number of establishments and the number of establishments normalized to the population, for each RRHE. / Distribuição do número de entidades com sede em cada RRAS, do número de estabelecimentos e do número de estabelecimentos normalizados à população, para cada RRAS [14].

\begin{tabular}{|c|c|c|c|}
\hline & $\begin{array}{l}\mathrm{N}^{\circ} \text { de entidades com sede / } \\
\text { No. of entities established }\end{array}$ & $\begin{array}{l}\text { No de estab. } \\
\text { Number of estab. }\end{array}$ & $\begin{array}{l}\text { Estab. por } 100.000 \text { hab. / } \\
\text { Estab. Per } 100.000 \text { inhab. }\end{array}$ \\
\hline Bragança & 2 & 2 & 3,49 \\
\hline Chaves & 3 & 4 & 4,92 \\
\hline Viana do castelo & 9 & 12 & 4,76 \\
\hline Braga & 16 & 16 & 3,93 \\
\hline Mirandela & 2 & 4 & 4,20 \\
\hline Guimarães & 22 & 27 & 5,17 \\
\hline Felgueiras & 14 & 18 & 3,22 \\
\hline Vila Real & 5 & 9 & 4,48 \\
\hline Porto & 80 & 84 & 6,58 \\
\hline S. João da Madeira & 12 & 15 & 5,25 \\
\hline Viseu & 9 & 8 & 2,75 \\
\hline Aveiro & 15 & 18 & 4,54 \\
\hline Guarda & 3 & 3 & 2,68 \\
\hline Seia & 2 & 2 & 4,12 \\
\hline Covilhã & 2 & 2 & 2,17 \\
\hline Coimbra & 24 & 26 & 7,75 \\
\hline Lousã & 3 & 3 & 2,18 \\
\hline Castelo Branco & 5 & 5 & 6,64 \\
\hline Sertã & 0 & 1 & 2,37 \\
\hline Leiria & 12 & 15 & 5,69 \\
\hline Entroncamento & 14 & 19 & 8,23 \\
\hline Caldas da Rainha & 21 & 22 & 6,17 \\
\hline Portalegre & 2 & 3 & 5,97 \\
\hline Ponte do Sor & 1 & 1 & 2,54 \\
\hline Santarém & 8 & 9 & 5,00 \\
\hline Coruche & 2 & 1 & 1,47 \\
\hline Elvas & 3 & 4 & 5,85 \\
\hline Lisboa & 134 & 144 & 7,15 \\
\hline Montemor-o-Novo & 2 & 2 & 4,61 \\
\hline Évora & 8 & 8 & 9,23 \\
\hline Setúbal & 31 & 35 & 4,57 \\
\hline Moura & 1 & 3 & 8,00 \\
\hline Beja & 5 & 9 & 10,03 \\
\hline Sines & 6 & 7 & 9,79 \\
\hline Odemira & 0 & 0 & 0,00 \\
\hline Portimão & 8 & 10 & 5,33 \\
\hline Faro & 14 & 14 & 6,10 \\
\hline Total & 500 & 565 & \\
\hline
\end{tabular}


some health facilities (public and private) already had the latest equipment technology (multislice 64)" [19].

\section{Framework in the international context}

The trend for increase in the number of CT scanners seen in Portugal in recent years is also observed in other countries. The major differences among them are regarding the availability of CT scanners (Figure 2). However, significant differences were found in the number of CT scanners installed in the countries of the European Union (EU27) and the OECD. In Portugal, a ratio of approximately 26.0 TC scanners per million inhabitants was recorded, and this value exceeds the EU27 average by $61.5 \%$ (2007) (Figure 3) and the OECD average by $78.2 \%$ (Figure 4) $[8,9]$.

In analysing the global perspective, the statistics point to a larger number of CT scanners per million inhabitants in the countries belonging to the Health Care Levels (HCL) with greater numbers of physicians (Table sendo que algumas unidades de saúde (públicas e privadas) já dispunham de equipamentos de última geração (ex. 64 "cortes")" [19].

\section{Enquadramento no contexto internacional}

A tendência crescente do número de equipamentos de TC verificada em Portugal nos últimos anos é também observada em outros países do mundo, verificando-se grandes diferenças entre eles relativamente à disponibilidade da valência (Figura 2). Contudo, constataram-se diferenças significativas quanto ao número de equipamentos de TC instalados nos países da União Europeia (UE27) e da OCDE. Em Portugal, existia um rácio de aproximadamente 26,0 equipamentos de TC por milhão de habitantes, um valor que excedia a média da UE27, em $61,5 \%$ (2007) (Figura 3) e a média da OCDE em $78,2 \%$ (Figura 4) [8,9].

$\mathrm{Na}$ análise do panorama mundial, as estatísticas apontam um maior número de equipamentos de TC por milhão de habitantes nos países pertencentes aos níveis de cuidados de saúde (NCS) com maior número

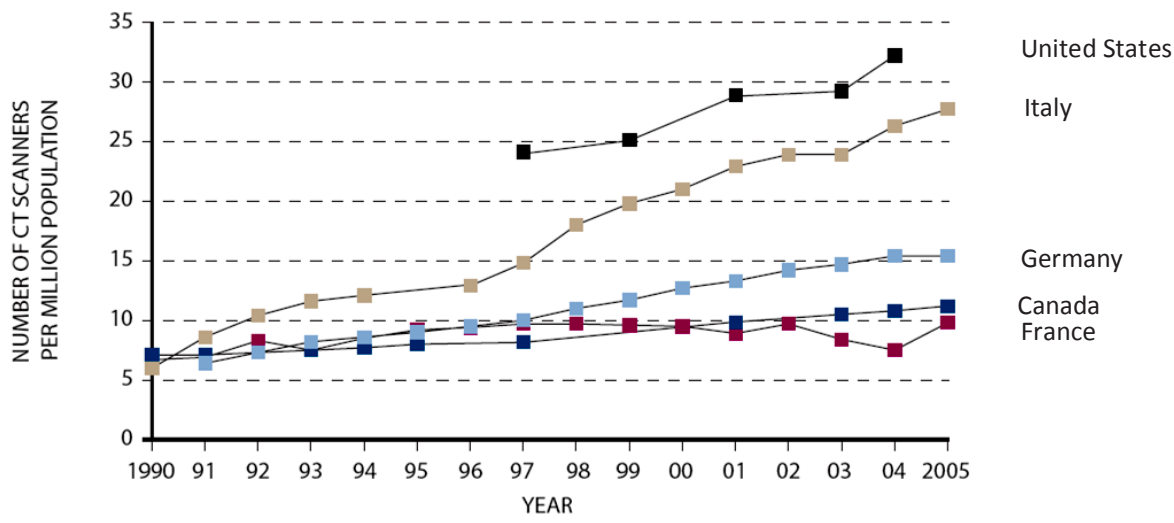

Figure 2 / Figura 2 - Number of CT scanners per million inhabitants, installed in the United States, Italy, Germany, Canada and France, between 1990 and 2005.

Número de equipamentos de TC por milhão de habitantes, instalados nos Estados Unidos, Itália, Alemanha, Canadá e França, no período entre 1990 e 2005. [9] 


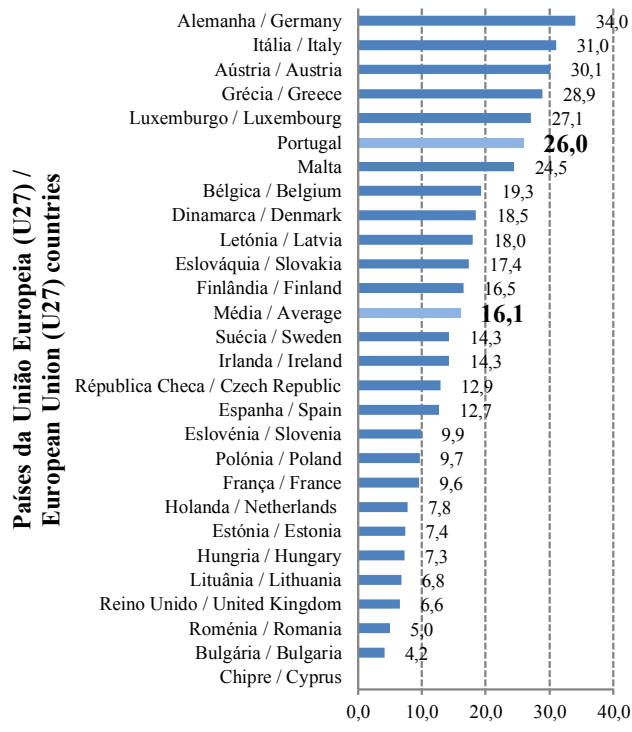

$\mathrm{N}^{0}$ de equipamentos de TC por milhão de habitantes / No. of CT scanners per million inhabitants

Figure 3 / Figura 3 - Number of CT scanners per million inhabitans in the countries of the European Union (EU27). / Número de equipamentos de TC por milhão de habitantes nos países da União Europeia (UE27) [9]

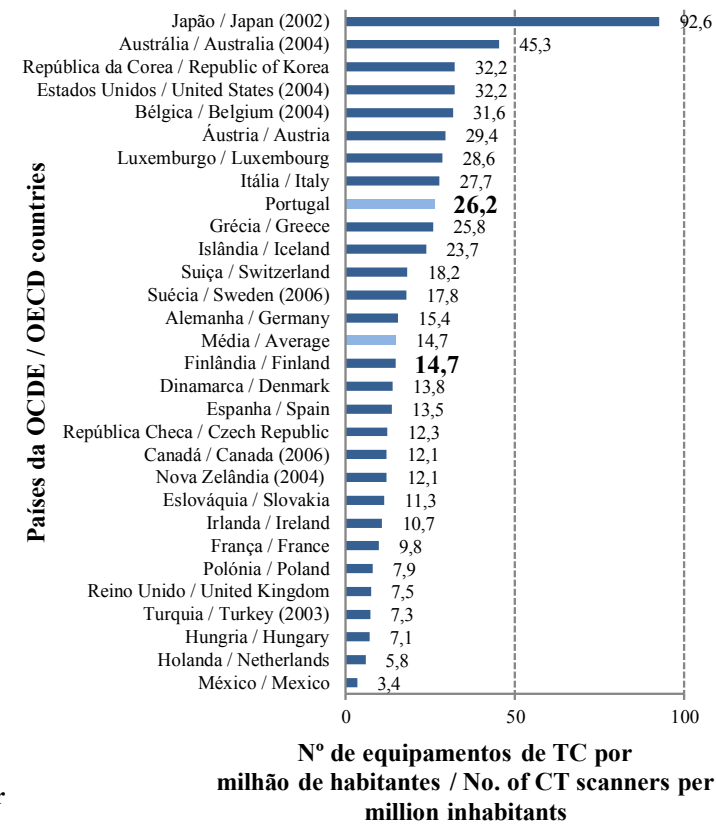

Figure 4 / Figura 4 - Number of CT scanners per million inhabitants in OECD countries. / Número de equipamentos de

TC por milhão de habitantes nos países da OCDE [8]

Table 3 / Tabela 3 - Number of CT scanners per million inhabitants installed in countries belonging HCL I, II, III and IV. / Número de equipamentos de TC por milhão de habitantes instalados nos países pertencentes NCS I, II, III e IV. [9]

\begin{tabular}{|c|c|c|c|c|}
\hline \multirow{2}{*}{$\begin{array}{l}\text { Equipamento } \\
\text { Equipment }\end{array}$} & \multicolumn{4}{|c|}{$\begin{array}{l}N^{\circ} \text { por milhão habitantes } \\
\text { no. per million inhabitants }\end{array}$} \\
\hline & $\begin{array}{c}\text { NCS I } \\
\text { (HCL I) }\end{array}$ & $\begin{array}{c}\text { NCS II } \\
\text { (HCL II) }\end{array}$ & $\begin{array}{c}\text { NCS III } \\
\text { (HCL III) }\end{array}$ & $\begin{array}{c}\text { NCS I } \\
\text { (HCL IV) }\end{array}$ \\
\hline $\begin{array}{l}\text { Radiologia Convencional } \\
\text { Conventional Radiology }\end{array}$ & 290 & 60 & 40 & 4 \\
\hline $\begin{array}{l}\text { Medicina Dentária } \\
\text { Dentistry }\end{array}$ & 440 & 60 & 10 & 0,1 \\
\hline $\begin{array}{l}\text { Mamografia } \\
\text { Mammography }\end{array}$ & 24 & 0,5 & 0,2 & 0,1 \\
\hline $\begin{array}{l}\text { Tomografia Computorizada } \\
\text { Computed Tomography }\end{array}$ & 17 & 2 & 0,4 & 0,1 \\
\hline $\begin{array}{l}\text { NCS I (HCL I): engloba tod } \\
\text { countries with at least one p } \\
\text { NCS II (HCL II): engloba to } \\
\text { all countries where there is } \\
\text { NCS III (HCL III) : englob } \\
\text { includes all countries where } \\
\text { NCS IV (HCL IV) : engloba } \\
\text { includes all countries where }\end{array}$ & $\begin{array}{l}\text { m pelo mer } \\
000 \text { inhabit } \\
\text { onde existe } \\
0-2,999 \text { inl } \\
\text { es onde exi } \\
\text { or to } 3,000 \\
\text { es onde exis } \\
\text { ee physiciar }\end{array}$ & $\begin{array}{l}\mathrm{m} \text { médico } \mathrm{p} \\
\text { hédico para } \\
\text { unts; } \\
\mathrm{n} \text { médico p } \\
00 \text { inhabitar } \\
\text { enos de méc } \\
10,000 \text { inha }\end{array}$ & $\begin{array}{l}00 \text { habitant } \\
-2.999 \text { habi } \\
000-10.000 \\
\text { or } 10.000 \mathrm{~h} \\
\text { ts. } \\
\end{array}$ & $\begin{array}{l}\text { includes all } \\
\text { es / includes } \\
\text { tantes / } \\
\text { ntes / }\end{array}$ \\
\hline
\end{tabular}


3). In general, countries belonging to HCL I, as Portugal, had an increased number of diagnostic imaging equipment per capita [9].

\section{Conclusion}

The increase in the number of CT scanners the national clinical technology landscape is unquestionable, especially in recent years. The greatest increase in the number of CT scanners was registered in hospitals, particularly between 2009 and 2011. Outside hospitals, the number of CT scanners has not changed significantly within the time interval with available data.

The availability of CT in Portugal is far superior to the average of the EU27 and the OECD countries. However, this does not necessarily indicate a suitable number of installed CT scanners to the national needs or that the number of performed exams is not excessive. These uncertainties deserve further investigation regarding the national guidelines for prescribing CT scans [20], as well as the relationship of $\mathrm{CT}$ with other imaging techniques available locally that compete directly with the $\mathrm{CT}$ for the same diagnosis.

Given the increased availability and use of CT, and the risks associated with the ionizing radiation of $\mathrm{CT}$ scans, it is more and more important to establish and comply with guidelines that promote radiation protection in each institution. In addition to knowledge regarding the number of CT scanners installed in Portugal, the knowledge of their geographical distribution and the degree of technological development in the national technology landscape will allow the adoption of strategies for radiological protection, categorised and applicable to local realities.

\section{Conflict of interest}

The authors declare no financial or personal relationships that could be perceived as potential conflict of interest. de médicos (Tabela 3). De um modo geral, os países pertencentes ao NCS I, como Portugal, apresentavam um maior número de equipamentos de diagnóstico por imagem per capita [9].

\section{Conclusão}

É inquestionável o aumento do número de equipamentos de TC no parque tecnológico clínico nacional, em especial nos últimos anos. Foi a nível hospitalar que se registou o maior crescimento do número de equipamentos, particularmente entre 2009 e 2011 . Em ambulatório, o número de equipamentos não sofreu grandes alterações no intervalo temporal com dados disponíveis. A disponibilidade da TC em Portugal é muito superior à média dos países da EU27 e da OCDE. Contudo, este facto não indica necessariamente que o número de equipamentos instalados é adequado às necessidades nacionais ou que o número de exames requisitados não é excessivo. Estas incertezas merecem a realização de outros estudos que se debrucem sobre as diretrizes nacionais para prescrição de exames de TC [20], bem como na relação da TC com outras valências de imagem disponíveis localmente que concorram diretamente com a TC para o mesmo diagnóstico.

Face ao aumento da disponibilidade e da utilização desta valência de diagnóstico, e aos riscos associados à radiação ionizante durante a realização dos exames de TC, é cada vez mais importante estabelecer e cumprir linhas orientadoras que promovam a proteção radiológica a nível local. Para além do número de equipamentos de TC instalados em Portugal, o conhecimento da sua distribuição geográfica e do grau de evolução tecnológica do parque tecnológico permitirá adotar estratégias de proteção radiológica, categorizadas e adequadas às realidades locais.

\section{Conflito de Interesses}

Os autores declaram não existir relações financeiras ou pessoais que possam ser entendidas como potenciais conflitos de interesse. 


\section{References / Referências}

[1] Kalender WA. Computed Tomography: Fundamentals, System Technology, Image Quality, Applications. 3 rd edition. Publics Publishing. Erlangen. 2011.

[2] Alfidi RJ, Haaga J, Meaney TF, MacIntyre WJ, Gonzalez L, Tarar R, Zelch MG, Boller M, Cook SA, Jelden G. Computed tomography of the thorax and abdomen; a preliminary report. Radiology 1975; Nov 117(2):257-64.

[3] Alfidi RJ. A Preliminary Report on Computed Tomography of the Thorax and Abdomen. Medical Imaging Techniques 1979; 91-103.

[4] Veiga-Pires JA, Kaiser MC. Preliminary report on a new mode of ct-scanning of the thorax. Computed Tomography 1980; 4:139143.[5] Davis DO, Marden D, Staples GS. A Head-Holding Device for Computed Tomography. Radiology 1975; Nov 117(2):480.

[5] Davis DO, Marden D, Staples GS. A HeadHolding Device for Computed Tomography. Radiology 1975; Nov 117(2):480.

[6] Arimitsu T, Di Chiro G, Brooks RA, Smith PB. White and Gray Matter of the Brain Differentiated by Computed Tomography. J Comput Assist Tomogr. 1977; Oct 1(4):43742.

[7] McNitt-Gra MF. AAPM/RSNA Physics Tutorial for Residents: Topics in CT Radiation Dose in CT. RadioGraphics 2002; 22:15411553

[8] Organization for Economic Co-operation and Development. OECD Health Data 2013, [2013 Oct 29] in: URL: http://stats.oecd.org/ index.aspx?DataSetCode=HEALTH_STAT
[9] United Nations Scientific Committee on the Effects of Atomic Radiation.. UNSCEAR 2008 Report: Sources and effects of ionizing radiation, Volume I, Annex A - Medical radiation exposures. United Nations. New York. 2010

[10] Committee on the Biological Effects of Ionizing Radiation, Board on Radiation Effects Research

Division on Earth and Life Studies, National Research Council of the National Academies. BEIR VII Phase 2: Health Risks from Exposure to Low Levels of Ionizing Radiation. National Academy of Sciences. Washington. 2006

[11] Shrimpton PC, Hillier MC, Lewis MA et al., Doses from Computed Tomography (CT) Examinations in the UK - 2003 Review. NRPB-W67. National Radiological Protection Board, Oxon, 2005

[12] Teles P, Sousa MC, Graciano P, Santos J, et al. Instituto Tecnológico e Nuclear. Unidade de Protecção e Segurança Radiológica. Dose Datamed 2 Portugal. Avaliação da exposição da população portuguesa a radiações ionizantens devido a exames médicos de radiodiagnóstico e medicina nuclear, Relatório sobre os resultados do projecto Dose Datamed 2 Portugal. 2002

[13] Rehani MM, Kalra MK, McCollough, Nagel HD. The International Commission on Radiological Protection. Annals of the ICRP, PUBLICATION 102: Managing Patient Dose in Multi-Detector Computed Tomography (MDCT). Elsevier. 2007
[14] Entidade Reguladora da Saúde. Estudo sobre a concorrência no sector da imagiologia Março de 2009.

[15] Direção Regional de Estatísticas da Madeira. Estatísticas da Saúde da Região Autónoma da Madeira no ano de 2009, Abril de 2011

[16] Direção Geral de Saúde. Direção de Serviços de Epidemiologia e Estatísticas de Saúde. Divisão de Estatísticas de Saúde. Elementos Estatísticos: Informação Geral: Saúde2008, Dezembro de 2010

[17] Serviço Regional de Estatísticas dos Açores. Estatísticas da Saúde 2011.Novembro de 2012.

[18] Direção Regional de Estatísticas da Madeira. Estatísticas da Saúde da Região Autónoma da Madeira no ano de 2010, Março de 2013

[19] Pascoal A, Carrasqueiro S, Vale F, Silva A, Encarnação P, Calado C. Associação Portuguesa de Seguradores. Os seguros de saúde privados no contexto do sistema de saúde português - Capítulo 5: Caracterização do estádio de inovação tecnológica em saúde em Portugal. 2009.

[20] Comissão Europeia. Proteção contra as Radiações 118: Diretrizes para a prescrição de exames imagiológicos. Luxemburgo. 2001 